\title{
Species of Heterothrips Hood (Terebrantia: Heterothripidae) from Central America
}

\author{
Axel P. Retana-Salazar ${ }^{1}$
}

\begin{abstract}
Heterothripidae is a family with three genera: Lenkothrips De Santis \& Sureda, Scutothrips Stannard, and Heterothrips Hood. Lenkothrips contains a single species from South America, Scutothrips contains four species, and Heterothrips has more than 60 species. Heterothrips has not been adequately defined. Some species in this genus are associated with host plants of economic importance. In this paper, three new species are described, two of them associated with flowers in fruit tree crops of the family Myrtaceae and the other with a plant in the family Malpighiaceae used as an ornamental. The new species can be distinguished as follows: Heterothrips lopezae n. sp. has remarkably different sculpturing on the pronotum compared with H. sericatus Hood and H. mimosae Mound \& Marullo and antennal segments III-IV are pale in colour. Heterothrips lankesteriensis n. sp. is distinguished by the presence of setose tubercles behind the eyes; this character is present only in one other species, $H$. pubescens Hood, which is clearly distinguished by the presence of pronotal sculpture and the sculpturing of the metanotum. Heterothrips hondurensis n. sp. has unique antennal morphology and is easily recognized from $H$. lyoniae Hood by the pedicel with divergent sides and antennal segment IV truncated not rounded as in H. lyoniae. A key to the Central American species of Heterothrips is provided.
\end{abstract}

Key words: Heterothripidae, Myrtaceae, Malpighiaceae, fruit crops, ornamentals.

Resumen. Heterothripidae es una familia que incluye tres géneros: Lenkothrips De Santis \& Sureda, Scutothrips Stannard, and Heterothrips Hood. Lenkothrips contiene una única especie de Sur América, Scutothrips contiene cuatro especies, y Heterothrips tiene más de 60 especies. Heterothrips no ha sido adecuadamente definido. Algunas especies dentro de este género han sido asociadas con plantas hospederas de importancia económica. En este trabajo, se describen tres nuevas especies, dos de estas asociadas con flores en árboles frutales de la familia Myrtaceae y la tercera con una planta de la familia Malpighiaceae utilizada como ornamental. Las nuevas especies pueden distinguirse como sigue: Heterothrips lopezae n. sp. presenta una muy marcada esculturación del pronoto diferente a la observada en $H$. sericatus Hood y H. mimosae Mound \& Marullo además los antenómeros III-IV son de color claro. Heterothrips lankesteriensis n. sp. se distingue por la presencia de tubérculos con setas detrás de los ojos; este caracter se halla presente solo en otra especie, $H$. pubescens Hood, de la cual es claramente distinguida por la presencia de escultura en el pronoto y la esculturación del metanoto. Heterothrips hondurensis n. sp. presenta una morfología de la antena única y es fácilmente separada de H. lyoniae Hood por la estructura del pedicelo con lados divergentes y el antenómero IV truncado y no redondeado como en $H$. lyoniae. Se presenta una clave para las especies centroamericanas del género Heterothrips.

Palabras clave: Frutales, Heterothripidae, Myrtaceae, Malpighiaceae, ornamentales

\section{Introduction}

Heterothripidae is a family with three genera: Lenkothrips De Santis \& Sureda, Scutothrips Stannard, and Heterothrips Hood. Lenkothrips contains a single species from South America, Scutothrips contains four species, and the Heterothrips has more than 60 species. The members of this family live in flowers, and are restricted to the New World, ranging from United States to Argentina (Mound and Marullo 1996).

Many species have been described from single collections or single individuals. Consequently, intraspecific and interpopulation variation in colour and structure has not been studied. Mound and Marullo (1996) provided a key for identifying more than 50 species of Heterothrips, but the key uses several characters based on colour. This key, in contrast to that of Bailey and Cott (1955), was based on an examination of all specimens of the described species. The authors utilized consistent structural differences when they could. They emphasized not only the lack of information on variation in structure in

${ }^{1}$ Centro de Investigación en Estructuras Microscópicas (CIEMic), Universidad de Costa Rica, Apartado 2060, San José, Costa Rica. e-mail: axel.retana@ucr.ac.cr 
most of the species, but also the lack of information on their host relationships. A recent phylogenetic analysis suggests that colour patterns may be good characters (Retana-Salazar 2006).

In this paper, three new species of Heterothrips are described. One of them may be important to fruit crops of Central and South America. An updated key for the Central American species is included. For species determination, specimens were closely compared with specimens in the collection of the author in the Universidad de Costa Rica, material of the collection of the Departamento de Parasitología de la Universidad Autónoma Agraria Antonio Narro (UAAAN) and material from the collection of IBUNAM as well several descriptions of some species from Mexico (Johansen 1979).

\section{Key to the species of Heterothrips in Central America}

1a) Lateral margin of head with a tooth behind the eye 2

1b) Lateral margin of head without a tooth 3

2a) Pronotum without sculpture lankesteriensis sp. $\mathrm{n}$.

2b) Pronotum sculptured pubescens Hood

3a) Antennal segment III pedicel more than 2 times as long as wide 4

3b) Antennal segment III pedicel equal or less than 2 times as long as wide 5

4a) Without craspedate lobes on posterior margin of abdominal tergites; antennal segment IV yellow in distal half 4b) With craspedate lobes on posterior margin abdominal tergites; antennal segment IV yellow fimbriatus Hood

5a) Metanotal sculpture with triangular area of straight overlapping lines of sculpture bearing microtrichia

5b) Metanotal sculpture with the usual concentric rings of microtrichia flavicornis Hood

6a) Pronotum with more than 45 fine transverse striations; pronotum brown sericatus Hood

6b) Pronotum with less than 45 fine transverse lines 7

7a) Forewing pale near base 8

7b) Forewing dark at base; pronotum with less than 35 transverse striations 9

8a) Antennal segments I-II yellow, V yellow in part, IV scarcely shaded at apex; ocellar setae III close together flavicruris Hood

8b) Antennal segments I-II brown, IV brown at apex but pale at base; ocellar setae III widely separated minor Hood

9a) Pronotum yellow mimosae Mound \& Marullo

9b) Pronotum dark brown lopezae sp. n. 
Heterothrips lopezae Retana-Salazar, new species (Figs. 1-3).

Diagnosis. This species is clearly distinguished from its congeners by the: a) extremely reduced pores of the sensoria, b) pronotal sculpture with no more than 2528 midtransverse reticulations, c) pronotum brown, d) antennal segment VI dark brown, e) male without glands.

Female macroptera: Colour: Body uniformly brown in both adults and teneral specimens. Antennal segments I-II dark brown, III yellow amber, IV-V brown, VI-IX dark brown. Leg I yellow, legs II-III with femur brown and tibia yellow. All tarsi yellow. Forewing totally dark brown (Fig. 1). Head: Wider than long, with sides almost parallel. Compound eyes each with 6 pigmented facets, 3 ventral facets pale amber, 3 marginal facets brown. Three pairs of ocellar setae, io III in position 2/3. Four to five pairs of postocular setae. Antennal segment III tripartite, pedicel short above disc (Fig. 2). Apical sensory area on III and IV with a single row of very small pores. Segment III 1.2-1.3 times longer than IV. Circular sensoria reduced on segments V-IX, coalescent on segments VI-IX. Pronotum: Wider than head and wider than long. Broad, transverse reticulation present, no more than 25-28 midtransverse reticulations. Few middiscal setae. Mesonotum: Wider than long, with concentric reticulation (Fig. 3); one pair of posteromedial setae under the medial transverse line. Furca well developed but without spinula. Metanotum: With concentric lines of minute microtrichia very close together. With two pairs of setae, one anterior and one posterior. With a pair of campaniform sensillae. Furca well developed and without spinula. Thoracic sternites: With discal setae well developed. Wings: With two rows of setae without gaps between setae; scale clubbed with two veins, the first with 11 setae and the second with one seta. Abdomen: Presence of a longitudinal ventral fold on tergites I-II, which suggests a membranous area. Tergite I with numerous discal microtrichia medially and laterally, with a pair of campaniform sensillae near the tergal posterior edge. Tergites I-V with lateral comb of microtrichia, III-V with a few marginal microtrichia medially, VIVIII with complete marginal comb, II-VII without rows of discal microtrichia medially, but with lateral transverse rows of microtrichia, VIII-IX with transverse fine rows of discal microtrichia. Sternites with a long microtrichial comb on posterior margin and many discal rows of microtrichia. Sternite VII with five pairs of very long medial discal microtrichia. Sternites III-VI with 6-8 marginal setae, VII with two pairs of discal setae laterally and median five pairs of marginal setae arising in front of the hind margin. Sternites II-III with a membranous grove. With craspeda lobed. Ovipositor: Well developed with 29 teeth.

Measurements (in microns). Holotype female macroptera. Body length 1140 . Head length 100 , width 170. Pronotal length 140 , width 250 . Forewing length 660. Tergite IX length 90, tergite X 70. Antennal segments I-IX lengths 9, 30, 72, 51, 36, 39, 21, 27, 21, respectively.

Male macroptera. Body length 600-740. Similar to female in body colour and structure but smaller with body more slender, sternites without glandular area. Genitalia: Basal apodeme narrow, with anterior projections rounded. Parameres slim near the insertion, enlarged at base and longer than the pseudopenis. Total length 156, width 72 , width at the neck of the parameres 27, width at the top end 18 .

Inmature II. Body length 500-700. Colour yellowamber. Body covered with peglike setae. Antennal segment III formed by four intrasegments covered with membranous integument, without apparent muscular bundles.

Material examined. Holotype female, Costa Rica, San José, San Sebastián, 29-VIII-1999, in flowers of Psidium friedrichsthalianum. Paratypes: 6 females, 7 males, same data as holotype; 1 female collected in San Antonio de Escazú, January 1991 in flowers of Agapanthus (deposited in Museo de Insectos de la Universidad de Costa Rica (MIUCR)).

Etymology. This species is dedicated to Professor Myrna López for her long and successful research in the taxonomy and ecology of fishes. 

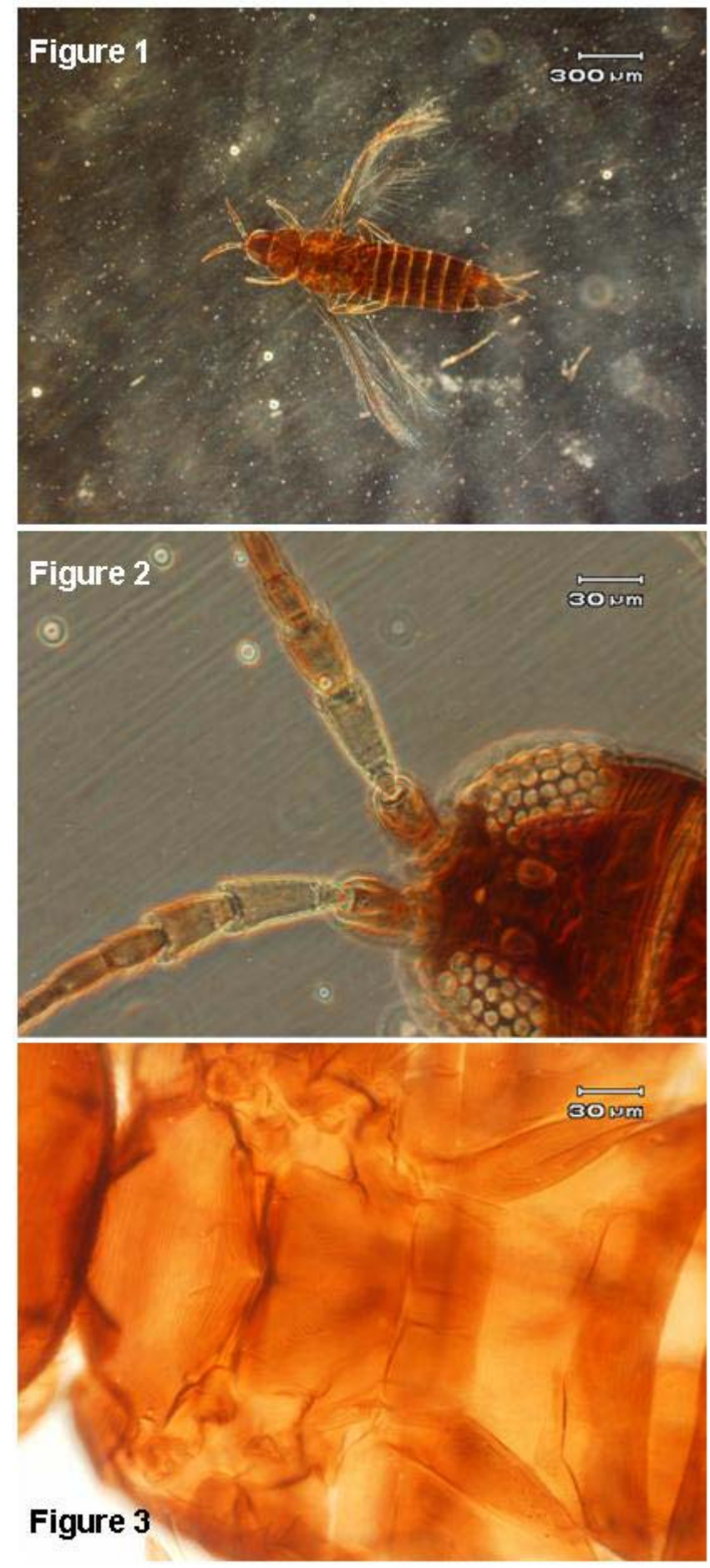

Figure 1. Heterothrips lopezae n. sp. Holotype.

Figure 2. Heterothrips lopezae n. sp. Antennal segments III-IV.

Figure 3. Heterothrips lopezae n. sp. Pterothorax.
Discussion. Heterothrips has been segregated into two informal groups of species. Heterothrips lopezae belongs to the so called Group I (Bailey and Cott 1955, Mound and Marullo 1996). In this group, the only species with characters similar to $H$. lopezae are $H$. mimosae and $H$. sericatus, but they show several differences in colour pattern, body size, sculpture of the pronotum, lengths of the antennal segments, absence of a glandular area on the tergites of the male, and reduced size of the males. One of the most relevant characters that shows phylogenetic importance is the extremely reduced diameter of the pores that conform the sensoria on antennal segments III-IV. In other genera with very different biology, this character seems to change with body size. Body size is not involved in this case, because within a range of body sizes (600-1140 microns) the character remains constant.

Biological data of the sort observed in this species are extremely rare in this group, where most species have been described from only one specimen or a few specimens collected only one time from a small, local population. The presence of a longitudinal ventral fold on tergites I-II, which suggests a membranous area with some particular function in this species, is unusual. Morphological studies in other groups of arthropods suggest that folds of this sort sometimes have a glandular function; if that is true, the glandular area in this case is present in females.

Another species with good biological data is Heterothrips peixotoa Del Claro, Marullo \& Mound from Brazil. The sex ratio for this species was 10 females: 1 male (Del Claro et al. 1997). This pattern is common in highly inbred species. A sex ratio of 1 female: 1 male in $H$. lopezae suggests that this species may be not be inbred.

Host-plants: The adults of Heterothrips and Scutothrips are commonly collected in low numbers from the flowers of Asteraceae or in the flowers of Fabaceae, Caesalpinaceae and Mimosaceae. One species, Heterothrips cacti Hood, has been collected in flowers of Cactaceae where they complete their biological cycle, but they also visit flowers of species in other families. However, in Costa Rica it is uncommon to find adults of these genera in any flowers other than Malpighiaceae. Given the absence 
of larvae or teneral specimens, it is difficult to know the true host-plant relationships. Adults are very mobile, often alighting in large numbers on flowers on which they do not breed. Several species of Heterothips and Scutothrips have been found in large numbers in the flowers of several genera of Malpighiaceae, such as Brachypterys, Byrsonima and Peixotoa (Del Claro et al. 1997). This may indicate that these are genuine host-plants, and that the Heterothripidae have a particular relationship to the species of Malpighiaceae. Heterothrips lopezae was found several times in five years in the flowers and buds of Psidium guajaba (L.) Kuntze and $P$. friedrichsthalianum (Berg.) Niedz.. In these flowers, both male and female adults were collected together with larvae. This suggests a host relationship with these plants. Nevertheless, this species does not exhibit host specificity, as may be possible for other species of Heterothripidae.

Field data: This species was collected several times in gardens in San José, Costa Rica at 1200-1400 m elevation from three different host plants. Two are economically important fruit trees, guava ( $P$. guajaba) and cas ( $P$. friedrichsthalianum). One female was collected from Agapanthus flowers in San Antonio de Escazú in the garden of a church.

Floral morphology and distribution of $\boldsymbol{H}$. lopezae: In the family Myrtaceae, the floral morphology is variable, from flowers that lacking petals (Syzigium) to others with little white petals, usually with radial symmetry, with both sexes and only five petals. In these genera the flowers do not have extrafloral nectaries. The flowers are rich in nectar and pollen, however, so they may be excellent sources of protein for the development of thrips.

Heterothrips lopezae adults and larvae live inside the flowers and within the chamber-like space between the sepals and the petals. The presence of larvae in this space suggests that the females lay eggs in this same place in the flower. Slide-mounted specimens never had pollen attached to the body, as has been reported for other species (Zerega et al. 2004). It is possible that this thrips does not pollinate the plant .
Population structure of $\boldsymbol{H}$. lopezae: The number of $H$. lopezae collected from January to April from the three host plants is shown in Table 1 . The teneral state was rare; perhaps this state is the most susceptible to attack from natural enemies. Remarkably, the numbers of males and females were very similar, with a sex ratio of $1: 1.1$. These flowers are not usually visited by thrips. In Costa Rica, it is not very common to collect thrips from the flowers of Myrtaceae, notwithstanding that when some thrips are recorded from these host plants they are commonly of the genus Frankliniella.

Table 1. Number of specimens of Heterothrips lopezae in flowers of the three host plants, San José, Costa Rica.

\begin{tabular}{lccc}
\hline State & $\begin{array}{c}\text { Psidium } \\
\text { guajaba }\end{array}$ & $\begin{array}{c}\text { Psidium } \\
\text { friedrichsthalianum }\end{array}$ & $\begin{array}{c}\text { Agapanthus } \\
\text { sp. }\end{array}$ \\
\hline Teneral 1 & 2 & 1 & 0 \\
Teneral 2 & 4 & 2 & 0 \\
Adults & 16f, $14 \mathrm{~m}$ & $8 \mathrm{f}, 7 \mathrm{~m}$ & $1 \mathrm{f}$ \\
Total & 36 & 18 & 1 \\
\hline
\end{tabular}

Heterothrips lankesteriensis Retana-Salazar, new species (Figs. 4-6).

Diagnosis. Heterothrips lankesteriensis is close to $H$. pubescens, from which it is distinguished by the smooth pronotum, the lateral microtrichiae, and the very small microtrichiae of the craspedal lobes. Antennal segment I has a peculiar structure as a basal fold. Concentric lines on metanotum are very close together and irregular, similar in appearance to $H$. lewisi Mound \& Marullo.

Female macroptera. Colour: Body uniformly brown. Abdominal sternum yellow. Antennal segment III yellow. Tibiae I brown, distal end of the coxa yellow. Wings dark with basal part translucent. All tarsi yellow (Fig. 4). Head: strongly striated, setae ioIII inner the ocellar triangle close tofether. Antennal segment I with a basal fold. Postocular furrow evident. Two posterior setae behind the postocular furrow (Fig. 5), the first on a prominent tubercle. Four to five pairs of postocular setae. Antennal segment with pedicel shorter above disc. Apical sensory area on III and IV in a single row. 
Pronotum: Wider than head and wider than long. Without sculpture. Few middiscal setae. Mesonotum: Wider than long, with concentric reticulation, with many lines of sculpture and one pair of medial setae. Furca well developed but without spinula. Metanotum: With concentric lines very close together and irregular, similar to $H$. lewisi. Two pairs of setae, one anterior and one posterior. With a pair of campaniform sensillae. Furca well developed and without spinula. Thoracic sternites: With discal setae well developed. Wings: With two rows of setae, without gaps between setae. Abdomen: Posterior margin of abdominal tergites with craspedate lobes (Fig. 6), with a fringe of microtrichia shorter than the lobe. Lateral areas with microtrichia well developed and widely separated. Sculpture zig-zag. Tergites III-V with medial microtrichiae, tergites VI-VIII with comb of microtrichiae complete and regular. Sternites with marginal setae only, never discal setae. Abdomen swollen. Ovipositor: Well developed with more than 20 teeth.

Measurements (in microns). Holotype female macroptera. Body length 1475. Antennal segments IIX lengths 25, 32.5, 117.5 (segment 95, pedicel 22.5), 50, 25, 25.5, 15, 15, 22.5. Craspedal lobes 12.5 . Microtrichiae of craspedal lobes 2.5.

Male macroptera. Body length 1075. Similar to female in body colour and structure but smaller with body more slender; with two postocular tubercles, each one with a tubercle; sternites with glandular area in IVVIII; abdomen slim. Genitalia: Basal apodeme narrow, with anterior projections rounded. Parameres slim near the insertion, enlarged at base and longer than the pseudopenis.

Material examined. Holotype macropterous female. Jardín Botánico Lankester, Paraíso, Cartago, 15-XI2006, in flowers of Malpighia glabra. Deposited in CIEMic-UCR. Paratypes with same data as the holotype, deposited in: 2 paratypes in MIUCR; 1 paratype in Senckenberg Museum, Frankfurt, Germany; 2 paratypes (1 female, 1 male) in Laboratorio de Zoología, Universidad Nacional Autónoma de México (UNAM), 1 paratype in Museum of Natural History of Bergen.
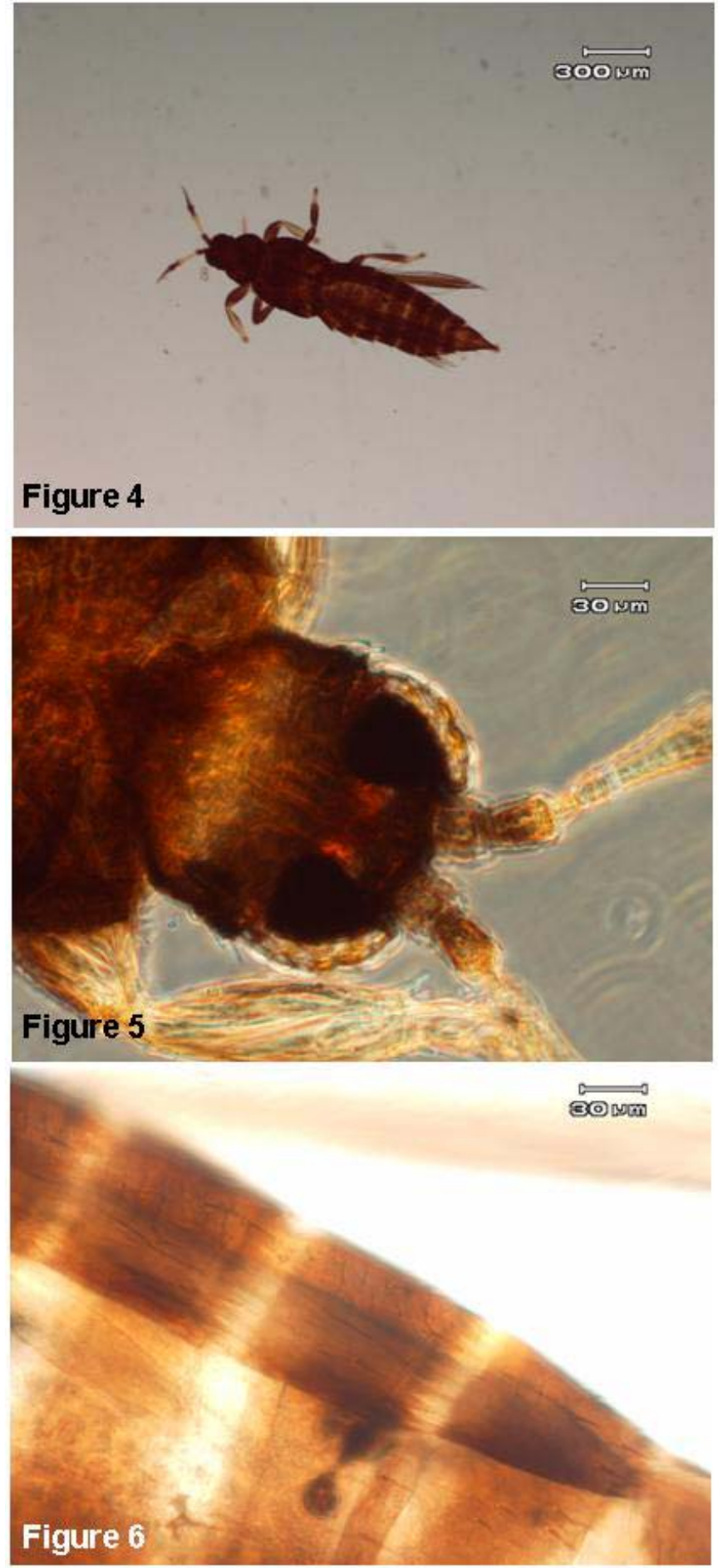

Figure 4. Heterothrips lankesteriensis n. sp. Holotype. Figure 5. Heterothrips lankesteriensis n. sp. Head.

Figure 6. Heterothrips lankesteriensis n. sp. Abdominal lateral terga. 
Etymology. This species is dedicated to Jardín Botánico Lankester where it was collected.

Discussion. A sex ratio of 1 female: 1 male in $H$. lankesteriensis suggests this species may not be inbred.

\section{Heterothrips hondurensis Retana-Salazar, new species (Figs. 7-8).}

Diagnosis. Craspedate lobes are absent on the posterior margin of the abdominal tergites and antennal segment IV is yellow in its distal half. The structure and length of the pedicel of antennal segment III suggests that this specimen belongs to a previously undescribed species with particular features not seen in any other species of the genus.

Female macroptera. Colour: Body uniformly brown in adults. All tarsi yellow. Antennal segments I-III yellow amber. Distally light brown, IV yellow in basal half, distal half light brown, V-IX brown. Forewing dark brown and translucent at base (Fig. 7). Head: Wider than long, with sides almost parallel. Compound eyes each with 6 pigmented facets, 3 ventral facets pale amber, 3 marginal facets brown. Three pairs of ocellar setae, io III in position 2/3. Four to five pairs of postocular setae. Antennal segment III well developed (Fig. 8), pedicel very large above disc, more than two times as long as wide and with divergent sides. Apical sensory area on III and IV with a single row of pores. Antennal segments III-IV truncated. Pronotum: Wider than head and wider than long. With broad, transverse reticulation. Few middiscal setae, no more than 28 midtransverse reticulations. Mesonotum: Wider than long, with concentric reticulation, one pair of posteromedial setae. Furca well developed but without spinula. Metanotum: With concentric lines very close together. Two pairs of setae, one anterior and one posterior. With a pair of campaniform sensillae. Furca well developed and without spinula. Thoracic sternites: With discal setae well developed. Wings: With two rows of setae, without gaps between setae. Abdomen: Tergite I with numerous discal microtrichia laterally. Tergites $\mathrm{I}-\mathrm{V}$ with lateral comb of microtrichia, $\mathrm{V}$ with a 10 marginal microtrichia medially, VI-VIII with complete marginal comb, I-
VIII with lateral rows of microtrichia. Sternites II-VIII with row of microtrichia and 10 well developed discal setae very near the posterior margin. Spermatheca small and well sclerotized. Ovipositor: Well developed with 33 very tiny teeth.

Measurements (in microns). Holotype female macroptera. Body length 1175. Antennal segments IIX lengths 25, 35, 75 (pedicel 25, segment 50), 45, 35, $35,15,15,10$.

Male. unknown.
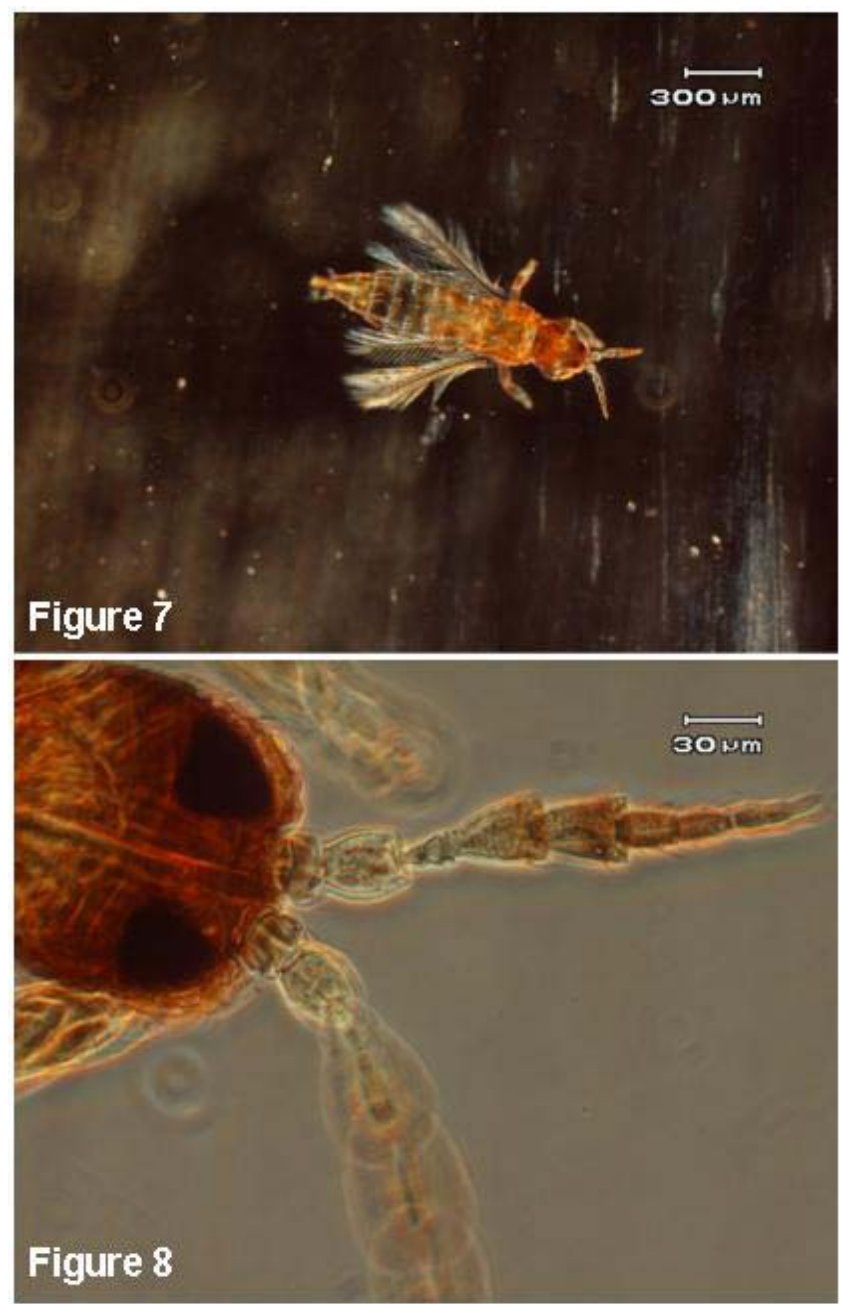

Figure 7. Heterothrips hondurensis n. sp. Holotype.

Figure 8. Heterothrips hondurensis n. sp. Antennae. 
Material examined. Holotype female, Tegucigalpa, Honduras, 1200 m, 7-VIII-1975. Collected by N.L.H. Krauss, mounted in balsam 6-XI-1975 by R. zur Strassen SMT T 68806. Determined by A.P. RetanaSalazar 13-III-2007. Deposited in Senckenberg Museum, Frankfurt, Germany.

Etymology. This species is named for the country where it was collected.

Discussion. This species is known only from a single specimen collected in Honduras from an unknown host.

Acknowledgements: I thank Richard zur Strassen for the loan of material from the Senckenberg Museum, Frankfurt, Germany, Laurence Mound and Roberto Johansen for their comments on the manuscript, Departamento de Parasitología de la Universidad Autónma Agraria Antonio Narro (UAAAN) for permission for revision of the collection of specimens, Centro Nacional de Sanidad Vegetal de Cuba for permission for revision of the collection of specimens Carlos Morales for botanical identifications, and Jerson Garita-Cambronero for the revision of the manuscript.

\section{References}

Bailey, S.F. and Cott, H. 1955. A review of the genus Heterothrips Hood (Thysanoptera) in North America, with descriptions of two new species. Annals of the Entomological Society of America 47: 614-635.

Del Claro, K., Marullo, R. and Mound L.A. 1997. A new Brazilian species of Heterothrips (Insecta: Thysanoptera) co-existing with ants in the flowers of Peixotoa tomentosa (Malpighiaceae). Journal of Natural History 31: 1307-1312.

Johansen, R.M. 1979. Seis nuevos tisanópteros (Terebrantia: Heterothripidae; Thripidae) de Chiapas, México. Anales del Instituto de Biología de la Universidad Nacional Autónoma de México 50 Serie Zoología (1): 159-178.

Mound, L.A. and Marullo, R. 1996. The Thrips of Central and South America: an introduction. Memoirs on Entomology International 6: 1-488.

Retana-Salazar, A.P. 2006. Los tisanópteros del grupo genérico Anaphothrips (Thysanoptera: Thripidae) con énfasis en América Central. Revista de Biología Tropical 55(1): 321-333.

Zerega, N.J.C., Mound L.A. and Weiblen G.D. 2004. Pollination in the New Guinea endemic Antiaropsis decipiens (Moraceae) is mediated by a new species of thrips, Thrips antiaropsis sp. nov. International Journal of Plant Sciences 165(6): 1017-1026.

Recibido para publicación el 25 de junio de 2008. 